\title{
A dança da política: trabalhadores, associativismo recreativo e eleições no Rio de Janeiro da Primeira República
}

\author{
The dance of politics: Workers, recreational associativism \\ and elections in the Rio de Janeiro of the First Republic
}

Leonardo Affonso de Miranda Pereira*

\section{Resumo}

Em janeiro de 1925 realizou-se na sede da Sociedade Dançante Carnavalesca Reinado de Siva, da Cidade Nova, a fundação de um "Centro Político Independente dos Operários do Distrito Federal". Com objetivos claramente eleitorais, ele pretendia fomentar candidaturas ligadas ao mundo dos trabalhadores para as eleições municipais que se aproximavam. Frente a uma produção historiográfica que aponta para o suposto distanciamento dos trabalhadores brasileiros da Primeira República em relação às questões políticas e eleitorais, a reunião realizada no Reinado de Siva aparece como meio de investigar o sentido político da criação e funcionamento, no período, de dezenas de pequenos clubes recreativos semelhantes, de modo a analisarmos as formas e lógicas próprias que pautavam a luta por direitos de seus componentes.

Palavras-chave: trabalhadores; eleições; política; associativismo; lazer.

\section{Abstract}

In January 1925 was held at the headquarters of the Reinado de Siva Dance and Carnival Society, in the neighborhood of Cidade Nova, the foundation of an "Independent Political Center of the Workers of the Federal District". With clearly electoral objectives, it intended to promote candidacies related to the world of the workers for the approaching municipal elections. Faced with a historiographical production that points to the supposed distancing of Brazilian workers from the First Republic in relation to political and electoral issues, the meeting held at the Reinado de Siva appears as a means of investigating the political sense of creation and functioning of dozens of similar recreational clubs, in order to analyze the forms and logics that guided the struggle for rights of its components.

Keywords: workers; elections; politics; associations; leisure.

\footnotetext{
* Pontifícia Universidade Católica do Rio de Janeiro (PUC-Rio), Departamento de História. Rio de Janeiro, RJ, Brasil. leonardo@puc-rio.br ${ }^{1}$
} 
Uma reunião muito diferente das habituais foi realizada em janeiro de 1925 nos salões da Sociedade Dançante Carnavalesca Reinado de Siva, da Cidade Nova. Fundada em junho de 1919, ela explicitava em seus estatutos o objetivo de "proporcionar aos seus associados um recreio honesto e agradável" com a organização de diversões como "saraus dançantes, bailes, quermesses, passeios e festas carnavalescas” (AN, IJ6 694). Essa proposta se traduzia, entre os sócios do clube, não apenas na preparação de desfiles carnavalescos nos dias dedicados a Momo, mas também na realização semanal de animados bailes dançantes. Segundo os jornais do período, os que tinham a chance de comparecer a esses eventos "se entregavam aos devaneios de bem ritmadas contradanças", em festas embaladas por "chorosos tangos e polcas” que se prolongavam até o amanhecer ("Pelos clubs carnavalescos", Gazeta de Notícias, 17 set. 1920; e "Carnaval", A Noite, 29 dez. 1920).

Frente a esse perfil, pode ter causado estranheza a muitos contemporâneos a notícia de que no início daquele ano de 1925 se organizara, em sua sede, uma reunião com o objetivo de fundar o "Centro Político Independente dos Operários do Distrito Federal” (“Cousas da política”, Jornal do Brasil, 22 jan. 1925). Segundo carta enviada pelos próprios participantes do encontro aos jornais, tratava-se da tentativa de constituir uma associação cujo objetivo era o de apresentar "um candidato genuinamente operário para a renovação do Conselho Municipal” nas eleições que se aproximavam. Por esse motivo, afirmava-se que a reunião era prestigiada por "grande número de associados da União dos Operários Estivadores e outras classes marítimas”. Sem menção aos membros de associações recreativas como aquela em cuja sede se realizava o encontro, a nota limitava-se a agradecer ao clube a cessão do espaço. À primeira vista, parecia tratar-se somente de uma reunião política que se aproveitou dos vastos salões de um dos principais grêmios dançantes do bairro.

Tal impressão de casualidade é reforçada, na atualidade, pela ênfase de parte significativa da historiografia brasileira sobre o suposto distanciamento dos trabalhadores da Primeira República em relação às questões políticas e eleitorais. Em uma bem articulada síntese historiográfica sobre os primeiros tempos do regime republicano no Brasil, que aponta para alguns dos problemas e tensões enfrentados no processo de consolidação do novo regime, Maria Efigênia Lage de Resende evidencia a distância que separa os ideais de República configurados por seus ideólogos das práticas políticas dos primeiros governos republicanos. Por mais que a ordem republicana se sustentasse em um arcabouço jurídico liberal, expresso pela Constituição de 1891, a partir do início da presidência de Campos Salles, em 1898, teria se gestado um "arranjo 
político" baseado em uma rede de relações e apoios que, baseados na força local do "coronel", sustentaria o poder das oligarquias estaduais, que por sua vez garantiriam a sustentação política do governo federal (Resende, 2003, p.91-92). Conhecido como a "política dos governadores", tal arranjo teria sido capaz de garantir a estabilidade do novo regime para além da vontade popular - o que levou autores como José Murilo de Carvalho a defender que, para os trabalhadores, "eram nulas as possibilidades de influenciar a política via participação eleitoral” ao longo das primeiras décadas da República (Carvalho, 2003, p.96-97).

Verdadeira para todos os trabalhadores, essa exclusão seria especialmente marcante no caso das mulheres, de todo excluídas dos processos eleitorais, e dos afrodescendentes - que, apegados a "seus valores, tradições e costumes", estariam mais distantes do universo da política formal, limitando-se a manifestar suas opiniões por meio de revoltas e movimentos de rua desenvolvidos “à margem dos mecanismos formais de participação" (Carvalho, 2003, p.107). Como resultado, as crises políticas atravessadas pela República a partir da década de 1920, que levariam em 1930 a uma primeira grande ruptura na ordem republicana, são vistas unicamente como o resultado das tensões internas a essas oligarquias, dado o suposto afastamento da classe trabalhadora em relação ao universo eleitoral gerado por esse sistema excludente (Ferreira, 1993).

Nessa perspectiva, parece reforçar-se a impressão de que os sócios de um clube dançante como o Reinado de Siva somente emprestaram seus salões para uma reunião de claro sentido político, sem que isso constituísse alguma forma de envolvimento com a causa. Mais forte ainda fica tal impressão ao atentarmos para o perfil específico dos sócios do clube em termos raciais e de gênero. De um lado, o fato de que em seu título ele se afirmasse como "familiar" apontava para uma característica singular dessas associações, e o fato de que elas fossem compostas igualmente por homens e mulheres, que assumiam em diferentes clubes um papel ativo muito distante da lógica masculina que marcava os clubes carnavalescos formados pelas elites da cidade (Schettini, 2002). De outro, embora seus estatutos afirmassem que ele era aberto a "número ilimitado de sócios, sem distinção de nacionalidade e de cor” (AN, IJ6 694), o noticiário sobre suas atividades deixava claro que ele era "composto exclusivamente de homens do trabalho rude da estiva" ("Notas recreativas", Correio da Manhã, 9 out. 1925). Por mais que pudesse haver exagero na definição, relatos como esse mostravam que se tratava de uma sociedade composta e frequentada pelos trabalhadores que residiam próximo à sua sede. Por funcionar de início em um sobrado alugado no número 246 da rua Senador 
Pompeu, o clube se localizava na região portuária, onde também residia a maior parte de seus sócios - como o estivador Arthur Maia de Araújo, eleito presidente no momento de fundação do clube, o qual morava no número 201 da mesma rua, ou Bernardo Moreira, que residia no número 176 da vizinha Barão de São Félix ("Incêndio", A Rua, 20 maio 1924; e "Na sede do Reinado de Siva”, O Jornal, 21 maio 1924). Tratava-se, não por acaso, de uma região de forte presença negra, expressa também no perfil étnico da classe dos estivadores (Cruz, 2000, p.260).

Não parece casual, portanto, que essa marca negra se evidenciasse na composição do corpo social do clube, tal como aparece na foto de um baile de 1922 (Figura 1), e nas feições do próprio Arthur Maia, seu primeiro presidente (Figura 2).

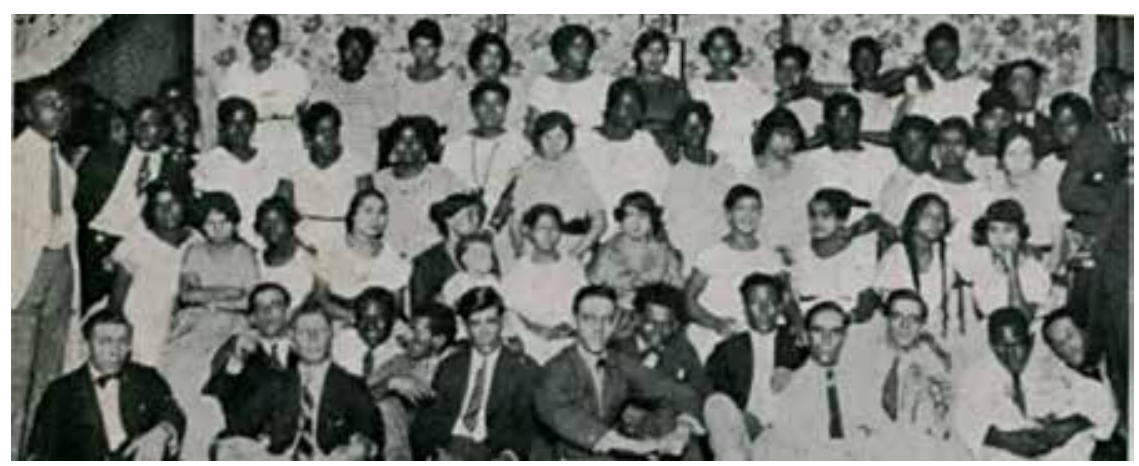

Figura 1 - O Malho, $1^{\circ}$ jul. 1922

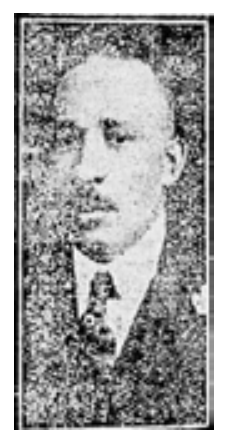

Figura 2 - "Sr. Arthur M. Araújo", A Noite, 25 jan. 1921

Além da significativa participação das mulheres, as fotos registram a marcante presença de negros e pardos no seio da associação. Por mais que não 
reivindicassem por meio do clube uma identidade exclusivamente negra, como acontecia com outras associações negras fundadas no período (Domingues, 2014), seus membros, assim como seu próprio presidente, seriam facilmente identificados como afrodescendentes, o que deixava claro o perfil social do grêmio do qual eram sócios. Não por acaso, em um momento no qual o Código Penal republicano criminalizava em seus artigos 157 e 158 as religiões de matriz africana, proibindo o uso de talismãs, o curandeirismo e outras formas de "magia e seus sortilégios", os fundadores do clube fizeram questão de afirmar, no segundo artigo de seus estatutos, que "a Diretoria respeitará as crenças religiosas de qualquer cidadão" (AN, IJ6 694).

Como consequência dessa composição, os frequentadores do grêmio estavam entre aqueles trabalhadores identificados por policiais e redatores da imprensa comercial da cidade como membros da parcela mais perigosa do mundo do trabalho: aquela que, vinda da experiência da escravidão, constituía o alvo preferencial de sua ação repressora. Era o caso do estivador Claudimundo Almeida da Rocha, que em setembro de 1922 foi preso por dois policiais quando se dirigia a um baile do Reinado de Siva apenas por "passar entre dous soldados de polícia, que se achavam nas proximidades”. Por ver nesse gesto "uma ofensa", os dois o agrediram, causando-lhe "ferimentos na cabeça e no rosto" ("Pobre do Claudimundo", A Noite, 4 set. 1922).

Sem ser casual, essa agressão era fruto da imagem de desordem e perigo construída no período para as sociedades recreativas formadas por trabalhadores negros e pardos. Era o caso do Reinado de Siva; descrito em 1926 por um jornal como uma das "sociedades recreativas e carnavalescas de pior fama da capital", era caracterizado na matéria como um clube frequentado pela "fina flor da malandragem", que teria sua frequência feminina composta "na sua quase totalidade do meretrício barato" ("No Reinado de Siva: um chauffeur assassinado", A Voz do Chauffeur, 15 nov. 1926). Definido como local de encontro de malandros e prostitutas, o clube era descrito pelas autoridades como um antro de crime e vadiagem, em um tipo de imagem que ajudaria a criar para associações como essa uma memória de distanciamento em relação aos temas relativos à política e à luta por cidadania.

Frente à força dessa imagem, expressa tanto na postura de policiais e jornalistas que se relacionavam com o clube quanto em análises historiográficas sobre o universo dos trabalhadores aparentemente distantes da política formal, a reunião política realizada em 1925 na sede do Reinado de Siva se converte em um enigma a ser decifrado. Para além da suposição de que se tratava de um simples empréstimo ocasional de seus salões para uma atividade de todo alheia 
a seus sócios, ela nos oferece uma pista sobre os limites da ideia de total afastamento dos trabalhadores da Primeira República em relação à política, sugerindo uma ligação entre a experiência dos sócios do clube e mecanismos formais de participação político-eleitoral. Para tentarmos compreender com mais densidade o sentido daquele evento, cabe analisarmos tanto o sentido político da lógica que alimentou a criação e o funcionamento de clubes como esse nos anos anteriores quanto o modo pelo qual seus sócios frequentemente fizeram deles um canal legítimo de expressão e busca por cidadania - caminho que pode nos fazer entender com outros olhos algumas das crises políticas enfrentadas pela jovem República brasileira ao longo da década de 1920.

\section{LAZER E MILITÂNCIA}

Quando foi fundado, em 1919, o Reinado de Siva não chegava a constituir uma novidade no universo do associativismo recreativo dos trabalhadores do Rio de Janeiro. Ao adotar como lema a frase "divertir, divertindo-se" ("Pelos clubs", A Noite, 6 dez. 1922), seus sócios mostravam a intenção de constituir mais uma das muitas sociedades dançantes fundadas no Rio de Janeiro nas primeiras décadas do século XX, em meio ao processo de afirmação dos novos ritmos sincopados que animavam sociedades do gênero em várias cidades atlânticas. Sua organização ligava-se, por isso, ao desenvolvimento de uma onda de associativismo recreativo que, ao longo das primeiras décadas da República brasileira, havia levado à criação de dezenas de clubes dedicados à dança e ao carnaval por toda a cidade.

Aos olhos de muitos dos homens de letras do período, a marca principal desses clubes era a de constituírem um espaço de alívio para os trabalhadores, no qual eles poderiam descarregar de modo aceitável as tensões da vida cotidiana. Por mais humildes que fossem, tais grêmios constituiriam, nessa perspectiva, espaços de lazer que permitiriam aos seus sócios esquecer por alguns momentos a dureza da vida que levavam. É o que sugere em 1922 um pequeno conto escrito por Coelho Netto sobre "um eleitor" (Coelho Netto, "Um eleitor", A Noite, 2 mar. 1922) - no caso, um certo Leandro, presidente do "Grêmio Familiar Dançante Flor de Abril”. Além de adepto da dança e da folia carnavalesca, ele era, segundo o cronista, um "patriota estreme", descrito como um cidadão "íntegro e cônscio dos seus direitos e deveres", motivo pelo qual nunca deixava de participar das eleições. Naquele ano, no entanto, o dia da votação coincidira com o carnaval, colocando Leandro em um impasse. "Deixar de fantasiar-se é, para ele, tanto como deixar de votar", explicava Coelho Netto. 
Como resultado, o protagonista, tendo se "excedido em certas coisas" durante a folia, e "com os ouvidos cheios da zoada carnavalesca", acabou "perdendo a noção do tempo", e se esqueceu das eleições, preferindo ir dormir na sede do grêmio. $\mathrm{O}$ autor ainda explica que mesmo se ele tivesse se lembrado, o voto seria impossível pelos trajes que Leandro vestia naqueles dias, pois "Morcego não vota". Ao acordar e perceber que perdera a votação sentiu-se ainda penalizado, mas um colega logo o consolou dizendo que "a vida não é só política". "Que importa este ou aquele? O Grêmio levantou a coroa", defende seu interlocutor, fazendo menção à vitória do clube no desfile de carnaval. Convencido do argumento, Leandro logo se esquece da política e passa a assobiar uma cantiga carnavalesca. Ao aliar simpatia e condescendência na imagem que faz de trabalhadores como o que aparece em sua crônica, Coelho Netto evidenciava uma visão que colocava o entusiasmo por tais clubes dançantes em contradição com o engajamento político, vendo neles um espaço de alienação em relação a uma possibilidade efetiva de participação eleitoral.

O próprio conto nos sugere, no entanto, outra forma de pensar a questão. Para além da crítica implícita em seu enredo, ela parte do reconhecimento de algo que podia ser notado, não sem estranhamento, por muitos dos leitores do jornal: o interesse pela política, demonstrado por muitos adeptos desse associativismo dançante. A própria verossimilhança do conto de Coelho Netto estava dada pela existência, desde o início do século XX, de muitos sinais de aproximação entre o associativismo dançante patrocinado pelos trabalhadores e as questões sociais e políticas mais amplas. Para entender o sentido do fenômeno para além da ironia lançada pelo literato sobre essa tentativa de aproximação entre lazer e política, cabe assim tentarmos compreender o modo pelo qual essa ênfase no associativismo dançante podia se articular, na experiência dos sócios de tais clubes, à possibilidade de fazer deles um meio de expressão e participação política mais direta.

Essa possibilidade se baseia, de início, no reconhecimento da ligação muitas vezes expressa entre os sócios desses clubes dançantes formados por trabalhadores e os interesses defendidos também por outras associações operárias mais diretamente voltadas para a política ou para a luta social. Para além do estranhamento manifesto pelo conto de Coelho Netto, desde o início do século XX eram muitos os exemplos de aproximação entre os sócios desses grêmios dançantes e alguns setores do movimento operário organizado. Era o que mostrava o caso do Amantes da União, um clube dançante fundado em 1898 na Ilha do Governador (“Associações”, Jornal do Brasil, 17 fev. 1901). Ainda que se tratasse de uma "sociedade exclusivamente familiar", criada com a finalidade de 
organizar bailes para seus associados, ela serviu de palco, em 1902, para a reunião de fundação da Associação Protetora dos Pescadores. Em um momento no qual estes se viam ameaçados pela chegada da Europa de novos navios "com os mais aperfeiçoados aparelhos de pesca", que prometiam "abarrotar o mercado diariamente com milhares de toneladas de peixe" ("Os pescadores", A Notícia, 15 dez. 1902), seu objetivo era o de reunir "todas as pessoas que pertencerem ou se interessarem pela classe dos pescadores" para defender os interesses da categoria, à qual pertenciam então boa parte dos moradores da localidade (“Associação Protetora dos Pescadores”, A Notícia, 15 dez. 1902). Era o caso, dentre outros, de Pio Dutra da Rocha e Arthur Magioli, dois dos três signatários da convocação da reunião que, além de participarem da organização da nova associação, eram membros ativos da diretoria do Amantes da União (“Associações”, Jornal do Brasil, 7 mar. 1901). Casos como esse mostram que, analisado em perspectiva histórica mais ampla, o empréstimo dos salões do Reinado de Siva para a reunião do "Centro Político Independente dos Operários do Distrito Federal" estava longe de constituir um acaso ou exceção.

Não era de se admirar, por isso, que muitas vezes esses clubes deixassem de lado sua rotina de bailes e festas para evidenciar sua proximidade e solidariedade com as causas que afetavam o conjunto dos trabalhadores cariocas. Foi o que fez em 1908 o Clube Carnavalesco Luz do Povo. Fundado em fevereiro de 1904 na mesma região em que surgiria depois o Reinado de Siva, ele tinha como sócios os trabalhadores da Companhia de Gás situada nas imediações, e se dedicava como muitos outros à organização de animados bailes que atravessavam toda a noite ("Club Carnavalesco Luz do Povo", Jornal do Brasil, 5 abr. 1904; "Club Carnavalesco Luz do Povo", Gazeta de Notícias, 12 fev. 1906; e "C. C. Luz do Povo", Gazeta de Notícias, 28 set. 1906). Apesar disso, a rotina do clube foi quebrada em abril de 1908 por um evento que não guardava aparentemente nenhuma relação com suas atividades: uma greve dos trabalhadores da Companhia de Gás. Ao deixar os subúrbios às escuras e diminuir sensivelmente a pressão do gás da região central, a paralisação dos foguistas podia ser sentida por toda a cidade. Ainda assim, as próprias autoridades reconheciam que os grevistas se mantinham "em completa ordem", obedecendo às determinações policiais que proibiam agrupamentos ao redor da fábrica. Para articular seu movimento, esses trabalhadores buscaram um espaço legítimo de reunião, do qual passaram a lutar por seus interesses: os salões do Club Carnavalesco Luz do Povo, onde já estava o advogado dos grevistas (“A greve na Companhia do Gás”, O Paiz, 12 abr. 1908). Transformada em epicentro do movimento, a sede do clube se manteve, durante sua vigência, "em sessão 
permanente" (“Os trabalhadores do gás”, Correio da Manhã, 13 nov. 1908). Sem deixar dúvidas sobre o envolvimento do grêmio carnavalesco com o movimento, sua diretoria publicou um anúncio em alguns dos principais jornais da cidade no qual noticiava que, "sendo a maioria dos sócios deste club operários da Fábrica de Gás", suspendia os bailes e passeatas festivas já agendados até o fim do movimento em virtude da greve ("C. C. Luz do Povo", Jornal do Brasil, 18 fev. 1908). Em um momento de enfrentamento, dissipavam-se assim as fronteiras entre o lazer e a luta, em processo pelo qual o Luz do Povo se assumia como uma sociedade operária.

Por mais que a participação do clube dos gasistas na greve tenha constituído um caso singular, outras posturas cotidianas de clubes do gênero mostrariam, nos anos seguintes, como os sócios desses pequenos clubes frequentemente fizeram deles um espaço de defesa dos interesses dos trabalhadores que os compunham. É o que sugeria em 1914 o caso da Sociedade Dançante Carnavalesca Recreio das Flores. Fundada em 1909, tratava-se de outra das associações dançantes da região da Cidade Nova que tinha também entre os estivadores sua base social ("Recreio das Flores", Gazeta de Notícias, 8 jan. 1909). Como acontecia em outros clubes, sua sede costumava também abrigar reuniões políticas dos trabalhadores que a compunham, como aqueles que formavam em 1914 o "Grupo dos Carbonários", ligado à Sociedade União dos Operários Estivadores ("Ecos do conflito entre estivadores", O Imparcial, 27 dez. 1914). Naquele ano, entretanto, os sócios do clube tratavam de deixar ainda mais clara sua ligação com as causas de interesse dos trabalhadores, envolvendo-se ativamente na passeata promovida pelos grêmios operários da cidade para celebrar o Primeiro de Maio (Figura 3).

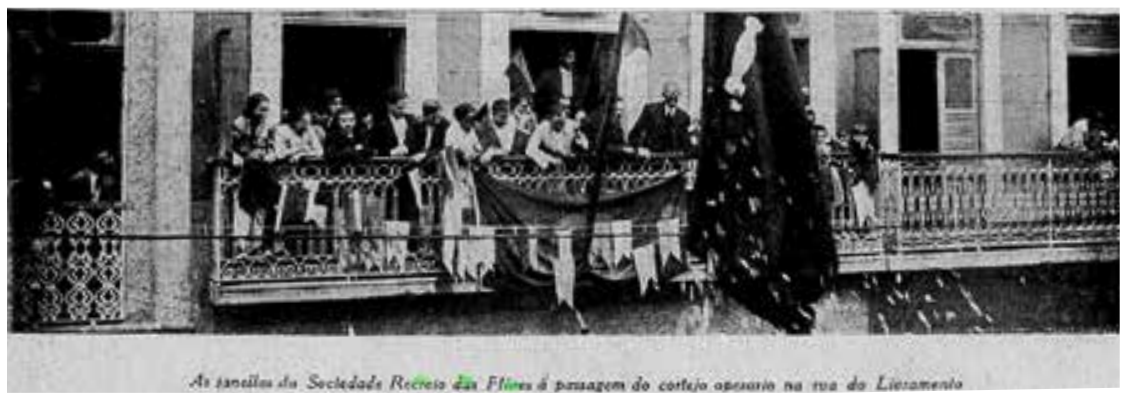

Figura 3 - Revista da Semana, 9 maio 1914

Com sua fachada solenemente enfeitada e embandeirada, os sócios e sócias do clube colocavam-se como parte da celebração, assumindo de forma 
inequívoca a identidade de trabalhadores. Mostravam, com isso, a fragilidade das fronteiras que poderiam separar as sociedades voltadas para o lazer daquelas organizadas de modo explícito para defender os interesses dos operários. $\mathrm{Na}$ mesma trilha, outras sociedades dançantes do gênero tratavam de se colocar abertamente na luta em favor de causas de interesse dos trabalhadores do Rio de Janeiro - como mostrava o festival realizado em 1917 no Jardim Botânico pelo "comitê de propaganda contra o analfabetismo, em benefício da instrução popular", que contou com a presença de sociedades similares como a Flor do Abacate, do Catete, a União da Floresta do Encantado e a Mimosos Crisântemos de Santa Tereza ("Festas", A Epoca, 4 fev. 1917).

Para além das diferenças existentes entre as diversas sociedades de cada região, configurava-se assim entre elas, em momentos de dificuldade ou enfrentamento, uma solidariedade política mais ampla, como aquela que se expressa em 1918 no bairro das Laranjeiras. Divididos entre a devoção ao Club dos Arrepiados e à União da Aliança, os moradores do local tinham em comum o fato de serem em sua maior parte operários da Fábrica de Tecidos Aliança, situada no bairro. No contexto de greve e mobilização dos operários têxteis que se verificava naquele momento, os diretores do primeiro desses clubes publicam nos jornais um comunicado pago no qual afirmam que, "em vista da época anormal que atravessa presentemente o elemento operário", definido como "o esteio" das duas sociedades dançantes existentes no bairro, deixaria de realizar sua passeata carnavalesca naquele ano, sugerindo à sociedade rival que fizesse o mesmo. A proposta era de que ao invés dos desfiles fossem realizadas "festas ao ar livre, onde divertir-se-iam conjuntamente os sócios das duas sociedades e o povo", o que seria capaz de produzir "grande efeito moral" ("Declaração da S. D. C. dos Arrepiados”, Gazeta de Notícias, 22 dez. 1918). Ainda que a União da Aliança tenha recusado a proposta por já se encontrar em processo de preparação de seu desfile, sua apresentação evidenciava o sentido político da solidariedade que os ligava, de forte base social. Ficava claro, em situações como essas, que era a defesa do interesse dos trabalhadores locais que unia diferentes grêmios que, para além de seu sentido recreativo, se configuravam também como espaços cotidianos de luta por direitos.

Parece explicável, por isso, que boa parte dos sócios e diretores desses clubes dançantes se mostrassem também ativos em outros grêmios de trabalhadores explicitamente voltados para a luta política. Essa era uma tendência que se anunciava desde o início do processo de proliferação desses clubes dançantes. Em 1903 o Pingas Carnavalescos, uma das primeiras sociedades do gênero do Engenho de Dentro, tinha em sua diretoria figuras como Trajano 
Pereira da Silva, que naquele mesmo ano aparecia como membro do conselho da União Operária do Engenho de Dentro ("Sociedade Pingas Carnavalescos", Correio da Manhã, $1^{\circ}$ ago. 1903; e "União Operária do Engenho de Dentro", Correio da Manhã, $1^{\circ}$ jul. 1903). Já na Gávea, bairro então habitado pelos trabalhadores têxteis da fábrica de mesmo nome, destacava-se nos primeiros anos do século XX a figura do militante socialista Luiz Barbosa, um escriturário da seção de panos da fábrica que era presença constante nos muitos clubes dançantes ali formados (Costa, 2014, p.53-61). Sem constituir um segredo, essa ligação era de conhecimento da própria polícia, que só contestava tal laço quando tinha registros de sublevação por parte dos sócios envolvidos com a política. Foi o que aconteceu em 1915 com a Sociedade Dançante Familiar Club dos Mangueiras: antes de conceder a licença necessária para o regular funcionamento do clube, o Inspetor do Corpo de Investigações alertava o Chefe de Polícia sobre seu presidente Cypriano José de Oliveira, que aparecia fichado nos arquivos policiais "como grevista", e sobre Caralampio Trilli, sócio do mesmo clube, caracterizado como um indivíduo "agitador, revolucionário perigoso", que teria tomado parte ativa nas greves de 1904 (AN, IJ6 563). Por mais que a polícia tentasse controlar os casos mais explícitos, situações como essas, comuns em diversos clubes, mostravam que lazer e militância se articulavam cotidianamente na experiência dos sócios de muitos desses clubes dançantes formados por trabalhadores.

É a partir dessa lógica que seria formada em 1919 a Sociedade Dançante Reinado de Siva. Como outras associações do gênero, ela tinha entre seus fundadores e primeiros diretores muitos operários que já atuavam nas associações de defesa da classe. Além de Arthur Maia, seu primeiro presidente, era o caso de João Paulo Rodrigues, Aggeu Silva e Pedro Paulo Rodrigues, militantes ativos da União dos Operários Estivadores. ${ }^{2}$ Por conta dessa origem o clube também se associava com frequência a causas capazes de expressar o perfil social de seus membros - como ocorreu em maio de 1920, quando trataram de organizar um baile para celebrar o Primeiro de Maio, ou no carnaval do ano seguinte, comemorado pelos membros da sociedade com um desfile em homenagem à Lei Áurea ("S. Reinado de Siva”, A Razão, 3 maio 1920; e "Reinado de Siva”, A Noite, 4 fev. 1921). Por mais que seu lema fosse "divertir, divertindo-se" ("Pelos clubs", A Noite, 6 dez. 1922), exemplos como esses mostravam que a ênfase no lazer que fomentou a formação do clube não se dissociava, na experiência de seus sócios, da luta cotidiana por direitos.

Frente a esse tipo de postura, a escolha da divindade hindu que aparece no título da associação assume um sentido mais claro. Como seus fundadores 
provavelmente explicaram a um jornalista no momento de sua fundação, "Siva era um pastor que aliciando os seus companheiros de classe sublevou-os contra o despotismo do Império Romano" ("A inauguração do Reinado de Siva”, Gazeta de Notícias, 21 jul. 1919). No contexto das festas carnavalescas, regidas pelo Deus Momo, a escolha dessa outra divindade vinha assim a colocar, em perspectiva festiva, a possibilidade da sublevação, configurando uma escolha por meio da qual seus sócios deixavam bem marcada sua perspectiva política.

\section{DOS BAILES Às URNAS}

O fato de que membros de sociedades dançantes como o Reinado de Siva frequentemente fizessem delas um espaço de defesa dos interesses dos trabalhadores sugere que tais grêmios estavam distantes da imagem de alienação e descompromisso para elas construída por homens de letras como Coelho Netto. Isso não basta, no entanto, para afastar a suposição do desinteresse e afastamento desses trabalhadores em relação aos processos eleitorais. Se as redes de solidariedade forjada por eles nesses espaços do associativismo recreativo muitas vezes se expressavam em uma deliberada tomada de posição a favor dos interesses mais amplos daqueles que compunham esses pequenos clubes, cabe ainda entender em que medida elas podem ter alimentado uma forma mais institucional de participação política, expressa pela via eleitoral.

Uma primeira dificuldade, nesse sentido, estava dada pela legislação eleitoral instaurada nos primeiros anos da República. Segundo o artigo $70 \mathrm{da}$ Constituição promulgada em 1891, o alistamento eleitoral estava vedado para os analfabetos, o que reduziria o número potencial de eleitores para cerca de $7,8 \%$ da população brasileira. Mesmo aqueles aptos a votar, no entanto, frequentemente não exerciam esse direito, frente ao medo das violências e fraudes que costumavam caracterizar os processos eleitorais. Os dados relativos às eleições realizadas ao longo da Primeira República mostram que a participação eleitoral efetiva se reduziu, no período, a um máximo de $3,4 \%$ da população total (Carvalho, 2003, p.104).

Para além desse quadro geral, no entanto, o interesse pela eleição demonstrado em 1922 por Leandro, o protagonista do conto de Coelho Netto, sugere uma postura diferenciada em relação à política eleitoral por parte de muitos dos sócios desses grêmios dançantes. Além de presidente do "Grêmio Familiar Dançante Flor de Abril”, o protagonista se mostrava um eleitor entusiasmado, que parecia não ver contradição entre suas duas paixões. Ainda que tenha se esquecido das eleições por conta da pândega carnavalesca, ele é apresentado 
pelo autor como um homem de forte "sentimento cívico", que "sabe de cor a Constituição", e que no período eleitoral "tinha o seu candidato, pelo qual trabalhou com entusiasmo e até com sacrifício da bolsa" (Coelho Netto, "Um eleitor", A Noite, 2 mar. 1922). Por mais que a história contada por Coelho Netto tratasse de ironizar essa suposta ambiguidade, sugerindo com o esquecimento do protagonista a preponderância da folia carnavalesca sobre o interesse eleitoral, a própria verossimilhança do personagem se apoiava em certo reconhecimento por parte do literato da aproximação promovida por muitos contemporâneos entre dois campos vistos como incongruentes por analistas da posteridade.

Essa aproximação tem como ponto de partida o reconhecimento por parte do literato de um interesse dos trabalhadores cariocas pelas eleições maior do que aquele pressuposto por autores que reafirmam uma imagem totalmente oligárquica e excludente para a Primeira República. Em que pesem os baixos números da efetiva participação eleitoral destacados por autores como José Murilo de Carvalho, pesquisas recentes têm demonstrado que muitos trabalhadores tentavam participar, nos limites de suas possibilidades, das eleições realizadas nos primeiros tempos da República brasileira (Dantas, 2010; Pinto, 2014). "Nesta terra o indivíduo pode não ter um pedaço de pão, mas um título eleitoral... é certo", dizia em 1904 a Vagalume, pseudônimo com o qual começava a ficar conhecido o jornalista negro Francisco Guimarães, um dos interlocutores com os quais conversou em uma visita noturna ao Engenho de Dentro (Vagalume, "Ecos Noturnos", A Tribuna, 17 mar. 1904; Pereira, 2015). Se muitas vezes essa tentativa parecia dificultada pelos limites impostos pela legislação ao efetivo alistamento eleitoral - como reconhece o próprio Vagalume em outra crônica da mesma série, na qual afirmava que o interesse pelas eleições muitas vezes esbarrava no fato de que as mesas de alistamento eleitoral estavam "todas entregues" aos poderosos locais, que controlavam quem podia ou não se alistar (Vagalume, "Ecos Noturnos", A Tribuna, 30 abr. 1904) -, clubes como o Reinado de Siva podem ter se constituído, para além de seus objetivos declaradamente recreativos, em canais de estímulo à afirmação e participação político-eleitoral de seus sócios.

Essa possibilidade de atuação eleitoral era evidenciada, em primeira mão, pela presença frequente na diretoria dessas sociedades de militantes e lideranças operárias engajadas na organização dos trabalhadores. Era o que acontecia no Pingas Carnavalescos - clube recreativo fundado em 1881 no bairro suburbano do Engenho de Dentro, uma das primeiras associações recreativas da cidade que, a partir do modelo festivo das até então destacadas Grandes 
Sociedades Carnavalescas, propusera-se a criar um espaço de lazer para os trabalhadores da região (“C. P. Pingas Carnavalescos”, Gazeta de Notícias, 8 jan. 1881). Como vice-presidente da associação aparecia, em 1893, um certo Miguel Paes Barreto, que como muitos dos moradores do bairro era maquinista das oficinas da Estrada de Ferro Central do Brasil (Cidade do Rio, 19 jun. 1893; e "E. F. Central do Brasil", Jornal do Brasil, $1^{\circ}$ abr. 1904). Em atitude comum aos membros de outros desses pequenos clubes dançantes, Miguel se mostrava envolvido com as causas de interesse dos trabalhadores, como sugeria naquele ano sua participação na campanha de arrecadação de fundos para as vítimas da guerra patrocinada por Floriano Peixoto contra seus opositores do sul do país ou o engajamento que teve 4 anos depois em uma comissão criada para combater a "excessiva carestia dos gêneros alimentícios" (Cidade do Rio, 17 maio 1893; e "Carestia dos gêneros”, O Paiz, 18 set. 1897). Por conta disso, fazia questão de harmonizar sua presença na diretoria do Pingas com uma participação ativa na Federação dos Trabalhadores do Brasil, para cujo comitê geral foi escolhido em 1899, e na União Operária do Engenho de Dentro, da qual aparecia em 1901 como conselheiro (Jornal do Brasil, 10 nov. 1899; e "Associações", O Paiz, 10 jul. 1901). ${ }^{3}$ Por conta dessa sua atuação ao mesmo tempo recreativa e social, foi saudado em 1900 por uma nota publicada no Jornal do Brasil para celebrar seu aniversário como o "batalhador da classe operária e o salvador da sociedade Pingas Carnavalescos" (Jornal do Brasil, 29 set. 1900) - posição reafirmada, no ano seguinte, por uma pequena notícia publicada na imprensa suburbana que ressaltava os "muitos e relevantes serviços coletivos e sociais" que ele teria "prestado à sua classe" ( $O$ Echo Suburbano, 28 set. 1901).

Se o envolvimento com as causas operárias por membros dos pequenos clubes dançantes espalhados pela cidade já se apresentava como uma constante, a forma de expressão desse engajamento por parte de Miguel Paes Barreto assumiria, em 1895, dimensões singulares. Em um momento no qual a nova ordem republicana brasileira tentava ainda se afirmar, com a realização de algumas das primeiras eleições regidas pelas regras eleitorais definidas pela Constituição de 1891, que proibia o voto de analfabetos, ele já se esforçava por fazer de sua militância carnavalesca e operária um meio de participar, a seu modo, do processo eleitoral. Na véspera das eleições municipais realizadas naquele ano, publicou na Gazeta de Notícias uma pequena nota na qual, descrevendo-se como um "socialista", pedia votos para o "distinto operário Manuel de Magalhães Viega” “"Operário socialista”, Gazeta de Notícias, 6 jan. 1895). No ano seguinte, tratou ainda de publicar outra nota em defesa de 
Augusto Vinhaes, que descrevia como um "glorioso batalhador" sempre ao lado dos "verdadeiros operários". "Cerremos fileiras em torno de nosso defensor, de nosso dedicado amigo Augusto Vinhaes", afirmava na nota, em uma conclamação aos trabalhadores colocados sob sua influência para apoiar aquele que seria candidato a deputado federal nas eleições parlamentares realizadas em dezembro do mesmo ano (Miguel Paes Barreto, "Aos proletários", Jornal do Brasil, 13 abr. 1896; e "A Liga Operária do Distrito Federal", Gazeta de Notícias, 23 dez. 1896).

Por mais que não se tratasse de uma atuação direta da diretoria dos Pingas Carnavalescos no pleito eleitoral, a postura de Miguel Barreto evidenciava a lógica que alimentava o engajamento de muitos dos que se colocavam como diretores de associações do gênero, os quais se aproveitavam das redes neles construídas para exercer influência eleitoral. ${ }^{4}$ Em suas andanças pelo Engenho de Dentro, Vagalume, então o principal cronista dos subúrbios cariocas, atestava em 1904 o quanto a ligação com o Pingas era um elemento de peso eleitoral para as lideranças da região. Era o caso de figuras como o Capitão Sampaio e Alfredo Badaró dos Santos, tenente da Brigada Policial, chefes políticos na zona suburbana da cidade que eram membros ativos do clube (“Sociedade Pingas Carnavalescos”, Progresso Suburbano, 20 set. 1902). Por terem nos sócios do clube uma de suas bases principais, dependiam do engajamento destes para garantir sua força nas urnas. "As simpatias de que gozava o Sr. tenente Badaró, perdeu-as na célebre cisão dos Pingas Carnavalescas e mais se acentuou com a sua entrada e consequente presença, no dia do carnaval, no préstito dos Pepinos", explicava a Vagalume um morador do Engenho de Dentro para justificar a perda da força eleitoral do tenente decorrente de sua mudança para outro clube do bairro (Vagalume, "Ecos Noturnos", A Tribuna, 2 abr. 1904).

Com o progressivo fortalecimento desse associativismo dançante entre os trabalhadores, a perspectiva política assumida por muitos desses pequenos clubes se tornaria ainda mais clara. Se entre os últimos anos do século XIX e os primeiros do XX era por iniciativa individual que alguns de seus diretores tentaram se aproveitar dos laços de solidariedade tecidos nessas associações para garantir o apoio a certos candidatos, ao longo da década de 1910 muitos passariam a usar o nome dos clubes para exercer uma atuação eleitoral mais clara e articulada. Foi o que aconteceu na Sociedade Dançante e Carnavalesca Flor do Abacate, do Catete, já então um dos mais tradicionais grêmios dançantes de trabalhadores da cidade. Em nota paga publicada no jornal O Século com o chamativo título "Eleições municipais - $1^{\circ}$ Distrito - S. D. C. Flor do 
Abacate", João de Aquino, então seu Primeiro Secretário, conclamava diretamente "os sócios e admiradores desta sociedade [a]o obséquio de sufragarem, nas próximas eleições para intendentes, os nomes dos nossos queridos amigos Victor de Vasconcellos da Veiga Cabral e Caio Julio Cezar Monteiro e Barros, jornalistas, dignos por todos os motivos" ("Eleições municipais - $1^{\circ}$ Distrito - S. D. C. Flor do Abacate”, O Século, 24 out. 1913). ${ }^{5}$ De forma direta, utilizava-se dos laços de solidariedade tecidos entre os membros do clube para fomentar uma participação eleitoral efetiva, que sustentasse a eleição de candidatos ligados ao interesse do clube.

A escolha do candidato indicado nada tinha de casual. Ainda que na nota Aquino justificasse a indicação pelo "tributo de gratidão" do clube com a "imprensa carioca”, que teria ajudado a garantir suas "inúmeras vitórias” no carnaval, a indicação parecia ligar-se às aspirações sociais mais amplas dos trabalhadores que compunham esse tipo de clube. É o que sugeria o evento de lançamento da candidatura de Veiga Cabral à Intendência pelo $1^{\circ}$ Distrito, realizado em setembro daquele ano na sede da Confederação Brasileira do Trabalho - que ficava no número 44 da mesma rua Senador Pompeu na qual o Reinado de Siva tinha sua sede ("O jornalista Da Veiga Cabral é apresentado candidato a intendente municipal”, A Epoca, 27 set. 1913). Na ocasião, quem dirigiu a mesa e patrocinou o lançamento da candidatura foi o advogado Evaristo de Moraes, militante socialista e defensor de muitas agremiações operárias, que nos anos anteriores havia participado da organização de diferentes partidos voltados à defesa dos trabalhadores (Batalha, 2009, p.106). Nas palavras do manifesto que leu na ocasião, o advogado justificava o lançamento da candidatura pela convicção de que, mesmo em um momento de "falência do regime representativo", no qual "a fraude eleitoral tem chegado ao mais alto grau", o "povo" não deveria "abdicar os seus mais sagrados direitos de se fazer representar no Conselho Municipal”. O apoio do Flor do Abacate à sua candidatura se amparava, portanto, em sua ligação com a causa de trabalhadores como os que compunham esse tipo de clube.

Apesar do apoio do diretor do Flor do Abacate, os candidatos por ele indicados não conseguiram se eleger. ${ }^{6} \mathrm{Nem}$ por isso clubes do gênero deixariam de insistir nessa postura de engajamento, valendo-se das redes de solidariedade constituídas entre seus sócios para buscar representatividade eleitoral. Formada também por trabalhadores de baixa renda da região portuária, em sua maioria negros e pardos, a União das Flores, outra das sociedades dançantes fundadas na vizinhança do Reinado de Siva, era descrita em 1907 por autoridades policiais como o Delegado do $14^{\circ}$ distrito como mais um palco de 
“constantes desordens" (AN, GIFI 6C 211). Por mais que fossem vítimas de avaliações como essa, no entanto, os diretores e sócios do clube faziam questão de utilizá-lo como meio de expressão e participação política. Como exemplo dessa postura, promovem em junho de 1915 um animado baile para celebrar o "reconhecimento" da vitória de Vicente Piragibe na eleição para deputado federal realizada em 30 de janeiro daquele ano ("O reconhecimento do Dr. Vicente Piragibe", A Epoca, 24 jun. 1915).

Assim como Victor da Veiga Cabral, o candidato apoiado anos antes pela diretoria do Flor do Abacate, Vicente Piragibe era jornalista, exercendo então a direção do jornal $A$ Epoca - um dos que dedicavam cobertura mais generosa às atividades dos pequenos clubes dançantes. Embora não fosse do Partido Liberal, sua forte oposição à ordem fraudulenta e excludente dos sucessivos governos republicanos o levava a receber apoio de figuras como o próprio Evaristo de Moraes, que definia sua possível eleição como um sinal de "moralização política” (Evaristo de Moraes, "Eleição federal”, A Epoca, 29 jan. 1915). Valendo-se de seu jornal, fez por isso uma campanha na qual se colocou todo o tempo do lado dos interesses dos trabalhadores. Em um comício realizado em Bangu, bairro de forte presença operária, um trabalhador local chegou a afirmar que ele seria "o verdadeiro amigo das classes proletárias" ("O próximo pleito”, A Epoca, 26 jan. 1915). Ainda que estivesse longe de constituir uma candidatura efetivamente operária, Piragibe colocava-se assim, naquele pleito, como o candidato capaz de representar os interesses dos homens e mulheres que compunham a União das Flores e outros clubes do gênero.

Vitorioso nas urnas, tendo alcançado a segunda maior votação no $2^{\circ}$ distrito de acordo com a contagem de todos os grandes jornais da capital, Piragibe foi saudado por representantes de clubes dançantes como os Infantis de Santa Cruz e os Heróis da Piedade, cujo orador o chamou em um discurso proclamado em meio a um baile de "paladino dos oprimidos" ("Notas carnavalescas", A Epoca, 4 fev. 1915; e "Nos subúrbios", A Epoca, 10 fev. 1915). Poucos dias depois da eleição, no entanto, ele viu sua posse ameaçada por uma manobra da junta eleitoral que, mediante fraudes nos livros de ata de diferentes seções, tentava tirar seu nome da relação de eleitos. Para resistir à manobra, o candidato iniciou pelas páginas de seu jornal uma campanha pública pelo reconhecimento de sua eleição (“As falcatruas eleitorais do Sr. Vasconcellos”, A Epoca, 8 fev. 1915). ${ }^{7}$ De tanto insistir, acabou por conseguir do juiz responsável uma declaração escrita atestando não ser sua a assinatura que constava dos livros eleitorais que colocavam em dúvida sua eleição (“O grande escândalo eleitoral", A Epoca, 10 fev. 1915). 
O caso ainda se prolongaria pelas semanas seguintes, levando à instauração de uma comissão de inquérito na Câmara Federal para apurar o caso ("Nota avulsas", A Epoca, 10 abr. 1915). Como resultado dos trabalhos dessa comissão, a eleição de Vicente Piragibe foi finalmente reconhecida no dia 22 de junho (“O reconhecimento de Vicente Piragibe", A Epoca, 23 jun. 1915). Era em comemoração a esse reconhecimento que os sócios da União das Flores promoviam sua festa. Ao seu modo, com danças e brindes festivos no lugar de discursos e atos políticos solenes, eles mostravam "com cordialidade e alegria" sua posição crítica em relação às fraudes eleitorais e seu apoio ao candidato que conseguia seu lugar no Congresso Nacional ("O reconhecimento do Dr. Vicente Piragibe”, A Epoca, 24 jun. 1915). O próprio fato de celebrarem na ocasião não a eleição de Piragibe, e sim o "reconhecimento" de sua vitória, sugeria que os sócios do clube estavam conscientes dos desafios então impostos pela ordem republicana para a sua participação eleitoral. Frente aos entraves e dificuldades criados pela legislação republicana para a participação formal dos trabalhadores nas eleições e pelos vícios do processo eleitoral que se tornavam uma das marcas da Primeira República, esses clubes dançantes se convertiam em espaços de efetiva mobilização e participação, por meio dos quais o conjunto dos seus sócios tratava de se posicionar politicamente.

Mais intensa no caso do apoio a candidatos ao Legislativo municipal ou federal, esse tipo de mobilização se faria presente mesmo em campanhas de maior fôlego, como as disputas presidenciais. Ainda que tomados por parte da historiografia como desinteressados pelo processo político nacional, muitos dos sócios desses clubes mostravam ter engajamento ativo nas campanhas para a presidência da República. Era o caso de Didimo Soares, sócio e vice-presidente da própria União das Flores, que em 1913 foi um dos signatários de uma convocação para a reunião de lançamento da candidatura presidencial de Lauro Sodré, descrito como "o candidato do povo" ("O candidato nacional", A Epoca, 24 maio 1913). O mesmo candidato havia sido apoiado, em 1905, por Cypriano José de Oliveira, membro ativo do Club dos Mangueiras - sociedade composta, segundo um relatório policial de 1915, por "negociantes, operários e empregados de estiva", mas que teve dificuldade para conseguir sua licença por abrigar na sua diretoria o próprio Cypriano, descrito como "grevista" (“Quem deve ser o futuro presidente?", Correio da Manhã, 15 mar. 1905; e AN, IJ6 563). Casos como esses mostravam o interesse de muitos dos sócios desses pequenos clubes dançantes pelas eleições presidenciais. Sem ver nenhuma contradição entre esse engajamento político e o esforço de organização e participação em um clube dedicado ao lazer, trabalhadores como eles faziam de seus 
clubes dançantes um meio de articular eleitoralmente seus pares a partir de uma solidariedade tecida cotidianamente em bailes e outras atividades recreativas.

É bem verdade que muitas vezes essa tomada de posição eleitoral se dava em perspectiva individual, em geral patrocinada por alguns dos diretores desses pequenos clubes. Preferencialmente escolhidos entre os sócios que sabiam escrever e que tinham empregos estáveis, como forma de facilitar a obtenção de suas licenças de funcionamento junto à polícia, eles representavam a parcela dos sócios desses grêmios que estaria apta a participar do processo eleitoral segundo a legislação vigente. Longe de se limitar aos momentos de disputa eleitoral, no entanto, a participação política de tais clubes se evidenciaria ainda em muitas outras ocasiões cotidianas, nas quais os próprios clubes apresentavam institucionalmente suas posições e inclinações. Colocando-se como entidades políticas, muitos deles passaram a oferecer seu apoio a diferentes autoridades governamentais. É o que aconteceu em março de 1910, quando J. J. Seabra, então deputado federal pela Bahia, regressava à capital federal depois de uma excursão ao seu estado, na qual participara da campanha eleitoral em que o marechal Hermes da Fonseca vencera o civilista Rui Barbosa. Como parte da comitiva que o recepcionou no cais e o levou em préstito festivo até sua residência, estavam três indivíduos "representando o Club Flor do Abacate, conduzindo o estandarte" da associação e um "carro com comissão da Sociedade Carnavalesca Mimosos Miosótis", além de dois "representantes da sociedade particular Flor da Gávea” ("Dr. J. J. Seabra”, Correio da Manhã, 29 mar. 1910; e "Dr. J. J. Seabra”, A Imprensa, 29 mar. 1910). No ano seguinte, quando Hermes da Fonseca já era presidente, foi a vez de outros clubes como o Ameno Resedá, o Prazer do Castelo, o Retiro da América, o União das Rosas e outros se juntarem ao Flor do Abacate em um desfile de homenagem a ele no dia de seu aniversário ("Marechal Hermes", Correio da Manhã, 12 maio 1911). Em julho de 1911, da mesma forma, Hermes da Fonseca seria recebido por uma "comissão operária" quando de seu regresso à capital após uma viagem à Bahia, em manifestação que teve o apoio de "sociedades operárias" como as próprias Flor do Abacate e Ameno Resedá, além de outras como a Flor da Aliança ("Regresso do Presidente da República", A Imprensa, 23 jul. 1911).

Atitudes como essa ajudavam a evidenciar o sentido político da ação desses pequenos clubes. Ao se colocarem ao lado de Hermes da Fonseca depois de uma campanha especialmente disputada contra Rui Barbosa, os membros desses grêmios faziam deles um meio de lutar por seus direitos e aspirações. Se no momento das eleições seus sócios muitas vezes tentavam eleger 
representantes legítimos da causa dos trabalhadores, no caso da política nacional eles tratavam de estabelecer alianças e negociações com aqueles que ajudassem a garantir seu espaço, em uma forma de ação política bem conhecida pelos ex-escravos e seus descendentes que haviam feito desse tipo de postura um meio de lutar pela própria liberdade por dentro das redes do paternalismo senhorial (Chalhoub, 2003). Não por acaso, o apoio a Hermes da Fonseca era retribuído pelo presidente com uma deliberada valorização desses clubes - como aconteceu com o Ameno Resedá, cujos sócios foram recebidos no domingo de carnaval de 1911 pelo presidente em sua residência particular "com a maior satisfação", em encontro regado a "cerveja, vinhos, licores, refrescos e doces". Dias depois era a vez do Flor do Abacate, também do Catete, receber do presidente o "honroso convite" para se exibir a ele, "com sua pompa de sempre, no Palácio Guanabara" ("Ameno Resedá", e "Flor do Abacate", Jornal do Brasil, 28 fev. 1911). Por mais que nem todos os membros desses grêmios dançantes pudessem efetivamente participar do processo eleitoral, eles mostravam assim fazer de seus clubes um meio de fazer política, garantindo apoio a àqueles que contemplassem seus interesses.

Frente ao caráter cada vez mais frequente que esse tipo de postura política dos clubes dançantes assumiria nos anos seguintes, a reunião realizada em 1925 nos salões do Reinado de Siva parece ganhar um sentido mais claro. Longe de se limitar a ceder seu espaço para a fundação do "Centro Político Independente dos Operários do Distrito Federal”, o clube se constituía em uma das bases de estruturação da nova associação. Não por acaso, entre os participantes daquela reunião estavam sócios do Reinado de Siva como João Ribeiro de Campos, que havia sido em 1921 seu vice-presidente ("Cousas da política", Jornal do Brasil, 22 jan. 1925; e "Carnaval”, A Noite, 12 jan. 1921); Pedro Paulo Rodrigues, que em 1920 atuava como "ensaiador" do clube nos preparativos para o carnaval ("Reinado de Siva”, O Jornal, 23 dez. 1920.), e Adelino Antonio da Silva, membro da União dos Estivadores que 1920 havia feito seu "batismo" no grêmio da Cidade Nova como "Lord Fica Firme" ("Os estivadores", Jornal do Brasil, 4 jan. 1915; e "S.D.C. Reinado de Siva”, Gazeta de Notícias, 6 jan. 1920). Ao fazerem de seu ambiente de lazer um espaço também de luta e reivindicação de direitos, esses e outros membros do Reinado de Siva mostravam como o clube era para eles um meio de articulação política, o que do ponto de vista deles não estava em contradição com os objetivos propriamente recreativos da associação. 


\section{A POLÍTICA DO COTIDIANO}

Ainda que o caso da reunião realizada no Reinado de Siva possa sugerir a existência de uma ligação direta entre as atividades do clube dançante e a fundação do Centro Político realizada em sua sede, para os participantes daquela reunião as diferenças entre as duas instituições se mostravam também muito claras. Se nos dias de carnaval, de desfile e de festa era o estandarte de cada clube que definia a solidariedade expressa entre seus sócios, a associação política fundada naquele ano de 1925 tinha uma pretensão mais ampla, capaz de abranger membros de diferentes associações recreativas. Não por acaso, a reunião de fundação do novo centro era presidida por José da Rocha Soutello, que além de ter ocupado posições de relevo no movimento operário carioca dos anos anteriores - como a presidência da União dos Estivadores e da Confederação Brasileira do Trabalho, posições que serviram de base em 1913 para sua candidatura ao Conselho Municipal pelo $1^{\circ}$ Distrito ("Coluna operária”, A Epoca, 28 out. 1913; Batalha, 2009, p.160) - havia sido poucos anos antes presidente da sociedade dançante Recreio das Flores, cuja sede ficava também na região portuária ("Recreio das Flores", Jornal do Brasil, $1^{\circ} \mathrm{fev}$. 1921). Da mesma reunião participava ainda Eloy Anthero Dias, que ficaria mais conhecido como Mano Elói. Embora fosse também um estivador que militava nos sindicatos da categoria, que em 1918 dizia ser perseguido pela polícia por ser "grevista" e em 1920 aparecia como secretário do "Sindicato de Resistência dos Trabalhadores em Trapiche e Café" ("O comércio de café e a Resistência", A Razão, 12 ago. 1918; e "Sindicato R. dos Trabalhadores em Trapiche e Café”, A Razão, 6 mar. 1920), Mano Elói seria mais lembrado nas décadas seguintes por suas atividades carnavalescas - expressas não só nos cargos que ocupou em sociedades dançantes como o Cachopas do Minho, mas também nos muitos sambas que compôs e na sua participação, em 1947, na fundação da Escola de Samba Império Serrano (“Aviso", Jornal do Brasil, 6 set. 1929; Cunha, 2016). Ao se juntarem para a fundação de um Centro Político de Trabalhadores, esses membros de diferentes associações dançantes e carnavalescas mostravam que as redes de solidariedade tecidas por meio de seus centros de recreação, longe de separá-los, ajudavam no processo de afirmação de uma identidade política mais ampla, que podia se articular mediante uma luta comum por direitos que extrapolava suas disputas carnavalescas habituais.

Ainda que existissem rivalidades entre grupos de uma mesma região, por vezes gerando conflitos abertos e violentos entre eles, o apego comum ao associativismo dançante se consolidava a partir de uma rede que ligava os 
diferentes clubes em uma mesma causa. No caso do Reinado de Siva, eram explícitas suas ligações com os vizinhos do Recreio das Flores, ao qual seriam "filiados" - o que permitia que os componentes da sociedade vizinha participassem ocasionalmente de seus desfiles ("Carnaval - Reinado de Siva”, Correio da Manhã, 6 dez. 1922). Mesmo no caso de associações mais distantes como o Ameno Resedá, cuja sede ficava no Catete, seus sócios tratavam de estabelecer relações de cumplicidade, com grupos de um clube visitando rotineiramente os bailes patrocinados pelos outros ("Pelos clubs", Gazeta de Notícias, 19 ago. 1922). Como resultado, quando o Reinado de Siva ofereceu em 1925 um baile para reinaugurar sua sede após um incêndio que a havia destruído, o evento foi prestigiado por comissões de "muitas outras sociedades co-irmãs" - como o Cruzeiro do Sul, o Prazer do Estácio e o próprio Ameno Resedá (“Notas recreativas", Correio da Manhã, 13 out. 1925).

Do mesmo modo, era comum que os membros desses clubes dançantes frequentassem os festejos de diferentes associações, ou mesmo participassem de modo formal do quadro social de outros clubes. No caso do Reinado de Siva, até mesmo Custodio Lyra, que fora seu presidente em 1924, aparecia no ano seguinte como vice-presidente do Gualemadas, clube congênere do bairro vizinho de Santo Cristo ("Fogo - Na sede do Reinado de Siva", O Jornal, 21 maio 1924; e "Gualemadas", Jornal do Brasil, 18 mar. 1925). Por mais importante que fosse a identidade expressa pelo estandarte de cada clube, casos como esses deixavam claro a existência de uma base comum a todas elas, permitindo que os participantes daquele associativismo dançante que se fortalecia no período se pensassem como partes de um mesmo movimento, reconhecendo seus interesses comuns.

Os participantes desse associativismo dançante assumiam assim uma força que se tornava marcante para os contemporâneos, a qual ajudaria a afirmar seu espaço de legitimidade. Embora continuassem sujeitas ao controle e ao arbítrio da polícia, que muitas vezes tentava tolher suas atividades pela suspeição generalizada lançada sobre seus sócios (Pereira, 2013), o destaque que alcançaram ao longo dos primeiros anos do século XX, associado aos apoios negociados com o mundo político, já lhes permitia nos primeiros anos da década de 1920 reivindicar do poder público as mesmas vantagens e financiamentos garantidos desde o fim do século anterior às Grandes Sociedades carnavalescas frequentadas pelas elites cariocas. O próprio Reinado de Siva, junto a associações congêneres como o Ameno Resedá, o Flor do Abacate, os Cangaceiros do Caju e os Progressistas de Bangu, conseguiu em 1920 da prefeitura o valor de $200 \$ 000$ para financiar seus desfiles e bailes durante o 
carnaval ("Enfim! O carnaval”, Gazeta de Notícias, 15 fev. 1920). Mais do que uma dádiva, o financiamento das atividades desses clubes apresentava-se, do ponto de vista deles, como um direito pelo qual lutavam sob formas de ação cotidiana que marcavam suas atividades.

Evidenciava-se, em tais movimentos, uma delicada negociação entre os clubes e as autoridades, através das quais estas se mostravam conscientes da força política daquelas pequenas associações recreativas. Como consequência, ao longo da década de 1920 muitos desses clubes passaram a compor os gastos eleitorais de políticos como Paulo de Frontin, que havia sido prefeito da cidade em 1919. Já em 1921, uma nota do Jornal do Brasil afirmava que ele havia batido "o recorde das assinaturas em Livro de Ouro", que era o registro que cada clube fazia das doações recebidas, tendo doado 5 contos de réis só para o Recreio das Flores. "Já é dinheiro", reconhecia o redator da nota, apontando a generosidade expressa no alto valor da doação ("Indiscrições", Jornal do Brasil, 5 fev. 1921). A julgar pelos arquivos do próprio Frontin, tal prática perdurou ao longo de toda a década. Preparando-se para as eleições de 1930, ele relacionava entre suas "despesas eleitorais" do ano anterior as contribuições aos "Livros de Ouro" de outras sociedades formadas por trabalhadores como a Caprichosos da Estopa, o Arrepiados, o Flor do Catumbi e o Mimosas Cravinas. Com valores entre os $200 \$ 000$ doados ao Parasitas de Ramos e os $20 \$ 000$ recebidos pelo Paraíso da Infância, Frontin computava um gasto total de $670 \$ 000$ no primeiro semestre de 1929 somente na subvenção a esses clubes dançantes (IHGB, DL1305.041). Além de financiar tais clubes, Paulo de Frontin se mostrava interessado por suas atividades, mantendo-se informado sobre os desfiles e formas de organização de pequenos grêmios como o Ameno Resedá (Efegê, 1965, p.45). Como contrapartida, um clube como o Caprichoso da Estopa chega a aparecer entre aqueles que recebiam cédulas eleitorais de Frontin para a eleição ao Senado realizada naquele ano (IHGB, DL1305.037).

Apesar de todas as tentativas de afastar os trabalhadores cariocas da política ao longo da Primeira República, configurava-se assim a força conquistada pelos membros dessas pequenas sociedades dançantes. Com suas atividades cotidianas de lazer, eles se mostraram capazes de articular, em seus espaços compartilhados de experiência, redes de solidariedade que ajudaram a transformá-los em sujeitos relevantes do cenário político da capital federal, indicando a construção de um caminho de participação eleitoral que não se resumia ao exercício do voto. Ainda que esses homens e mulheres fossem em grande parte impedidos de votar nas eleições em virtude dos limites impostos pela ordem jurídica republicana, eles faziam de seus grêmios recreativos um 
canal de efetiva participação - o que lhes garantiu uma legitimidade que, ao corroer as bases de um sistema oligárquico forjado para excluí-los, ajudaria nas décadas seguintes a dar forma a um novo modelo supostamente mais inclusivo de nacionalidade.

\section{REFERENCIAS}

BATALHA, Claudio (Org.) Dicionário do movimento operário: Rio de Janeiro do século XIX aos anos 1920. São Paulo: Fundação Perseu Abramo, 2009.

CARVALHO, José Murilo de. Os três povos da República. Revista USP, São Paulo, n.59, p.96-115, set./nov. 2003.

CHALHOUB, Sidney. Paternalismo e escravidão em Helena. In: . Machado de Assis, historiador. São Paulo: Companhia das Letras, 2003. p.17-57.

COSTA, Mariana B. Entre o lazer e a luta: o associativismo recreativo entre os trabalhadores fabris do Jardim Botânico (1895-1917). Dissertação (Mestrado em História Social da Cultura) - Pontifícia Universidade Católica do Rio de Janeiro (PUC-Rio). Rio de Janeiro, 2014.

CRUZ, Maria Cecília Velasco e. Tradições negras na formação de um sindicato: Sociedade de Resistência dos Trabalhadores em Trapiche e Café, Rio de Janeiro, 19051930. Afro-Ásia, Salvador, n.24, p.243-290, 2000.

CUNHA, Maria Clementina P. Não tá sopa: sambas e sambistas no Rio de Janeiro de 1890 a 1930. Campinas: Ed. Unicamp, 2016.

DANTAS, Carolina V. Monteiro Lopes (1867-1910): um líder da raça negra na capital da República. Afro-Ásia, Salvador, n.41, p.167-209, 2010.

DOMINGUES, Petrônio. Cidadania por um fio: o associativismo negro no Rio de Janeiro (1888-1930). Revista Brasileira de História, São Paulo: Anpuh, v.34, n.67, p.251-281, 2014.

EFEGÊ, Jota. Ameno Resedá: o rancho que foi escola. Rio de Janeiro: Letras e Artes, 1965.

FERREIRA, Marieta de M. A reação republicana e a crise política dos anos 20. Estudos Históricos, v.6, n.11, p.9-23, 1993.

PEREIRA, Leonardo A. de M. Os Anjos da Meia-Noite: trabalhadores, lazer e direitos no Rio de Janeiro da Primeira República. Tempo, v.19, p.97-116, 2013.

. No ritmo do Vagalume: culturas negras, associativismo dançante e nacionalidade na produção de Francisco Guimarães (1904-1933). Revista Brasileira de História, São Paulo: Anpuh, v.35, n.69, p.13-33, 2015.

PINTO, Ana Flávia M. Fortes laços em linhas rotas: literatos negros, racismo e cidadania na segunda metade do século XIX. Tese (Doutorado em História) - Universidade Estadual de Campinas (Unicamp). Campinas, 2014. 
RESENDE, Maria Efigênia L. de. O processo político na Primeira República e o liberalismo oligárquico. In: DELGADO, Lucília de A. N.; FERREIRA, Jorge (Org.) O tempo do liberalismo excludente: da Proclamação da República à Revolução de 1930. Rio de Janeiro: Civilização Brasileira, 2003. p.89-120.

SCHETTINI, Cristiana. Os senhores da alegria: a presença das mulheres nas grandes sociedades carnavalescas cariocas em fins do século XIX. In: CUNHA, Maria Clementina P. Carnavais e outras $f(r) e s t a s:$ ensaios de história social da cultura. Campinas: Ed. Unicamp; Cecult, 2002.

\section{Arquivos consultados}

Arquivo Nacional (AN)

Instituto Histórico e Geográfico Brasileiro (IHGB)

\section{NOTAS}

${ }^{1}$ Doutor em História Social, Universidade Estadual de Campinas (Unicamp).

${ }^{2}$ Sobre Arthur Maia, ver "Carnaval”, A Noite, 25 jan. 1921, e "Operariado", Gazeta de Notícias, 13 abr. 1909; sobre João Paulo Rodrigues, "A inauguração do Reinado de Siva", Gazeta de Notícias, 21 jul. 1919, e "A eleição de ontem na Sociedade União dos O. Estivadores", A Epoca, 30 ago. 1915; sobre Aggeu Silva, "S.D.C.F. Reinado de Siva", Jornal do Brasil, 9 out. 1920, e "A União dos Operários Estivadores deu posse à nova diretoria", Correio da Manhã, 14 set. 1921; sobre Pedro Paulo Rodrigues, "Reinado de Siva", O Jornal, 23 dez. 1920, e “A sessão de ontem da União dos Estivadores”, Diário Carioca, 24 ago. 1928.

${ }^{3}$ Sobre a Federação dos Trabalhadores do Brasil - que, fundada em 1899, tinha por programa a "emancipação completa não só da classe assalariada, mas de todos os seres humanos, sem distinção de sexo, de cor ou de nacionalidade" -, ver BATALHA 2009, p.222.

${ }^{4} \mathrm{O}$ engajamento eleitoral de Miguel Paes Barreto continuaria forte nos anos seguintes. Eleito em 1909 presidente da União Operária do Engenho de Dentro, ele acaba dela eliminado "em consequência de haver o mesmo, na qualidade de presidente, cedido a sede social para a realização de uma conferência política". Cf. "União Operária do Engenho de Dentro”, A Imprensa, 16 set. 1909; e “A Notícia nos subúrbios”, A Noticia, 21 jan. 1910.

${ }^{5}$ Os dois candidatos eram lançados pelo Partido Republicano Liberal, comandado pelo senador Rui Barbosa. "Partido Republicano Liberal", O Paiz, 19 out. 1913. Sobre o cargo exercido então por João de Aquino na sociedade, ver "Notas carnavalescas", A Epoca, 15 jan. 1913.

${ }^{6}$ Veiga Cabral, o de melhor desempenho dentre eles, teve 2.083 votos, cerca de 1.200 a menos que o eleito com menor votação. Já o candidato mais votado do distrito teve 5.011 votos. Cf. O Paiz, 27 out. 1913. 
${ }^{7}$ Segundo a versão dos adversários de Piragibe, a mudança do resultado seria fruto do recebimento pelo cartório eleitoral de versões diferentes dos livros eleitorais da freguesia do Irajá, que atestariam serem falsos os resultados inscritos nos livros que atestariam a segunda colocação de Piragibe. Cf. "Falcatrua eleitoral", O Paiz, 6 fev. 1915.

Artigo recebido em 17 de janeiro de 2017. Aprovado em 30 de janeiro de 2017. 